6-1-2017

\title{
Copalic Acid Analogs Down-regulate Androgen Receptor and Inhibit Small Chaperone Protein
}

\author{
Nethrie D. Idippily \\ Cleveland State University \\ Qiaoyun Zheng \\ Cleveland State University \\ Chunfang Gan \\ Guangxi Teachers Education University \\ Aicha Quamine \\ Cleveland State University \\ Morgan M. Ashcraft \\ Cleveland State University
}

See next page for additional authors

Follow this and additional works at: https://engagedscholarship.csuohio.edu/scichem_facpub

Part of the Medicinal-Pharmaceutical Chemistry Commons

How does access to this work benefit you? Let us know!

\section{Recommended Citation}

Idippily, Nethrie D.; Zheng, Qiaoyun; Gan, Chunfang; Quamine, Aicha; Ashcraft, Morgan M.; Zhong, Bo; and Su, Bin Ph.D., "Copalic Acid Analogs Down-regulate Androgen Receptor and Inhibit Small Chaperone Protein" (2017). Chemistry Faculty Publications. 519.

https://engagedscholarship.csuohio.edu/scichem_facpub/519

This Article is brought to you for free and open access by the Chemistry Department at EngagedScholarship@CSU. It has been accepted for inclusion in Chemistry Faculty Publications by an authorized administrator of EngagedScholarship@CSU. For more information, please contact library.es@csuohio.edu. 
Authors

Nethrie D. Idippily, Qiaoyun Zheng, Chunfang Gan, Aicha Quamine, Morgan M. Ashcraft, Bo Zhong, and Bin Su Ph.D. 


\title{
Copalic acid analogs down-regulate androgen receptor and inhibit small chaperone protein
}

\author{
Nethrie D. Idippily, Qiaoyun Zheng, Chunfang Gan, Aicha Quamine, Morgan M. Ashcraft, Bo Zhong, \\ $\mathrm{Bin} \mathrm{Su}$
}

\author{
A R T I C L E I N F O \\ Article history: \\ Received 17 March 2017 \\ Revised 11 April 2017 \\ Accepted 12 April 2017 \\ Available online 13 April 2017 \\ Keywords: \\ Copalic acid derivatives \\ Small chaperone protein \\ Client protein \\ AR
}

Copaiba oil obtained from the trees of the Copaifera genus is composed of a mixture of sesquiterpenes and diterpenes. ${ }^{1}$ More than $75 \%$ of the composition of Copaiba oil was found to be sesquiterpenes. It has been used as a traditional medicine for wound healing and general inflammation. ${ }^{1-4}$ In recent years, studies of Copaiba oil and its components have revealed their potential anti-cancer activity. The Copaiba oil from C. multijuga species and its fraction have been reported to inhibit tumor growth in mice. ${ }^{5}$ Interestingly, a recent study by Feiella et al. revealed that hardwickiic acid, one of the diterpenoid acids existing in Copaiba oil, is an inhibitor of heat shock protein $27 \mathrm{kD}$ (HSP27). ${ }^{6}$

The discovery of the HSP27 inhibition by hardwickiic acid raised our interest in the other diterpene components in Copaiba oil. ${ }^{6}$ We speculate that other diterpenoid acids in Copaiba oil might interfere with this small chaperone protein as well since the diterpene components share similar structures. Further isolation of the individual components in the active sub-fractions followed by structural elucidation and biological activity examination led to the identification of two new small molecule chaperone inhibitors including copalic acid and 3-acetoxycopalic acid (Fig. 1). All three compounds inhibited the chaperone activity of HSP27 and $\alpha$-crys- tallin that shares a very similar structure with HSP27, suggesting that they are small chaperone protein inhibitors. ${ }^{7}$

The over-expression of small chaperone protein HSP27 in cancer tissues is correlated with anti-cancer drug resistance, which makes it a promising molecular target for drug development. ${ }^{8-11}$ HSP27 directly interacts with its client proteins affecting multiple steps in apoptosis, including cytochrome $c$ release, formation of apoptosome complex, and caspase-activation. ${ }^{8,10,12,13}$ Androgen receptor (AR) was reported to be one of the client proteins, and knockdown of HSP27 with antisense oligonucleotides (ASO) or siRNA could decrease AR level in prostate cancer cells. ${ }^{14}$ It has been well-documented that AR contributes to the development and progression of prostate cancer. Based on this discovery, a clinical trial was organized to examine the effect of HSP27 ASO OGX-427 for prostate cancer treatment, and the result was positive and promising. ${ }^{15}$ However, this strategy is associated with difficulties in drug delivery. It will be more desirable if small molecules that can down-regulate AR via the inhibition of small chaperone protein can be developed because of the higher bioavailability of small molecules compared to ASO. Nevertheless, down-regulating AR via small chaperone inhibitors seems to be a novel strategy for prostate cancer treatment.

Based on this hypothesis, developing more potent small chaperone inhibitors is the key, and AR protein level could be used to evaluate the potency of the compounds as well. However, the 


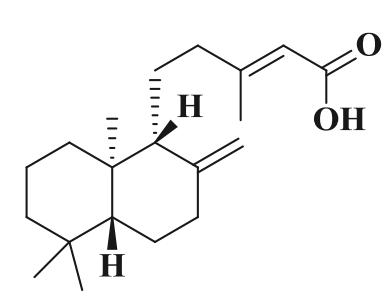

Copalic acid

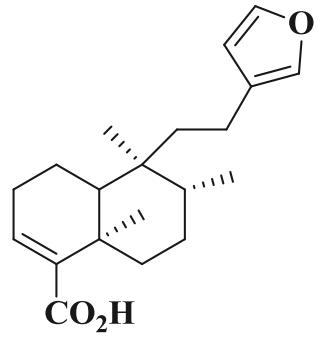

Hardwickiic acid

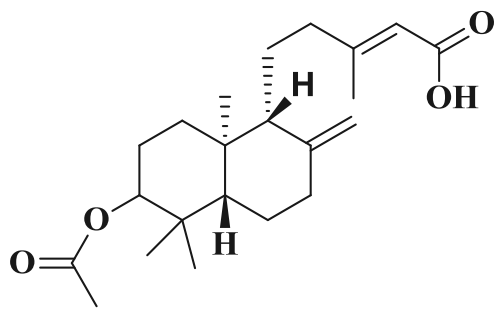

3-Acetoxycopalic acid

Fig. 1. Structures of copalic acid, hardwickiic acid, and 3-acetoxycopalic acid.

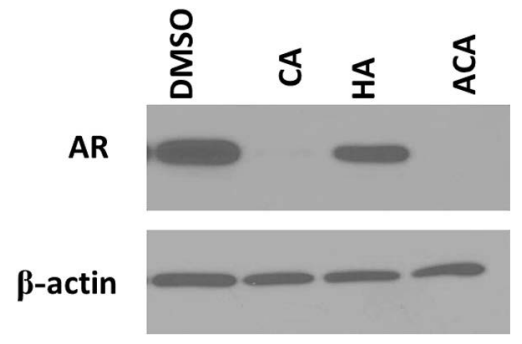

Fig. 2. Effects of copalic acid (CA) and hardwickiic acid (HA) and 3-acetoxycopalic acid (ACA) on the protein level of AR. LNCaP cells were treated with DMSO, three diterpenoid acids $(200 \mu \mathrm{M})$ for $48 \mathrm{~h}$. Levels of AR and $\beta$-actin were analyzed by Western blotting of cell extracts with specific antibodies. The experiment was repeated independently for three times and the representative one is presented.

in vitro chaperone inhibition assay has low sensitivity. Therefore, we focus on AR as the readout to establish a screening assay for the small chaperone inhibitor development. Although it has been reported in other studies that HSP27 inhibition with ASO or siRNA could lead to the degradation of $A R,{ }^{14}$ the effect of small molecule HSP27 inhibitors to AR protein level is still unclear. All three compounds in Fig. 1 showed direct inhibition of HSP27 and $\alpha$-crystallin, and they are different to the ASO or siRNA strategies. ${ }^{7}$ We hypothesize that these small chaperone inhibitors may also induce AR degradation. The AR protein level was determined after the treatment of LNCaP prostate cancer cells with these three natural products. The results exhibited that the small chaperone inhibitors could decrease the AR level in prostate cancer cells (Fig. 2). Copalic acid and 3-acetoxycopalic acid seem to show better activity compared to hardwickiic acid. Suppressing AR via targeting the chaperone protein with the small molecule inhibitor could be a novel approach in prostate cancer treatment or prevention.

In Copaiba oil, the abundance of copalic acid is much higher compared to the other diterpenoid acids. It was also more potent than hardwickiic acid and 3-acetoxycopalic acid in inhibiting small chaperone protein in our previous study, ${ }^{7}$ and more potent in downregulating AR in prostate cancer cells as well (Fig. 2). All the results make copalic acid a better lead compound for the development of potential drug candidates to down-regulate AR. Herein, a series of copalic acid derivatives were designed and synthesized in order to improve its potency to down-regulate AR.

Following the procedure of the isolation of copalic acid in our previous study, about $500 \mathrm{mg}$ copalic acid was isolated and purified. ${ }^{7}$ Then the carboxylic acid moiety of the compound was modified to different amide or ester analogs as indicated in Fig. 3. Different substituent groups were linked to copalic acid at the carboxyl group via a one-step reaction with dicyclohexylcarbodiimide (DCC). In general, $30 \mathrm{mg}(0.1 \mathrm{mmol})$ of copalic acid, $62 \mathrm{mg}$ of DCC $(0.3 \mathrm{mmol})$, and $0.15 \mathrm{mmol}$ of aromatic amine or phenol were stirred at room temperature in dichloromethane until the copalic acid was nearly fully consumed. The insoluble solid was filtered, and the solid was washed with dichloromethane. The filtrate was concentrated under vacuum and the residue was purified by column chromatograph to yield the product. A compound library of 15 copalic acid analogs was developed.

The compounds were examined for their activity to down-regulate AR in LNCaP cancer cells. For the testing, $200 \mu \mathrm{M}$ copalic acid was used as a positive control since $20 \mu \mathrm{M}$ copalic acid did not show any activity to decrease AR (data not shown). The results revealed that the modification of the carboxylic acid moiety generally increased the activity of some analogs. At $20 \mu \mathrm{M}$, compounds $3,5,12$, and 13 showed moderate activity to decrease the AR level, which is better than copalic acid. Compounds $\mathbf{4}$ and $\mathbf{7}$ seem to abolish all the AR in the cells at $20 \mu \mathrm{M}$. The results suggest that the aromatic moiety may promote the activity (Fig. 4). It is possible that the conversion of carboxylic acid moiety may enhance the penetration of the compounds into the cells, because the carboxylic acid group is ionized in the cell culture medium, and the generated negative charge limits the capability of copalic acid to penetrate the cell membrane. Considering some of the analogs showed improved activity, it is very likely that at least the changes to hydrophobicity contribute to this increased activity. Compounds $\mathbf{4}$ and $\mathbf{7}$ showed the best activity, but their aromatic ring structure cannot provide enough information to summarize what type of substituents on the phenyl ring might improve the activity. Subsequently, a dose-dependent experiment was performed to further examine the two compounds. The results exhibited their dose-dependent activity in LNCaP cells to suppress AR protein level. Particularly, compound 4 at $5 \mu \mathrm{M}$ dramatically decreased $\mathrm{AR}$ in the cells. In addition, compounds 4 and 7 showed IC $_{50}$ S of $1.73 \pm 0.72 \mu \mathrm{M}$ and $9.81 \pm 0.92 \mu \mathrm{M}$, respectively, to inhibit the growth of LNCaP cells, suggesting that they have the potential to be the hit compounds for further drug development to treat prostate cancer (Fig. 5).

Finally, the chaperone inhibition of the compounds was investigated with an in vitro chaperone assay. $\alpha$-Crystallin could stabilize dithiothreitol (DTT) induced insulin precipitation, and the chaperone function was inhibited by copalic acid, hardwickiic acid, and 3-acetoxycopalic acid in our previous study. ${ }^{7,16}$ Compounds 4 and 7 showed a clear inhibition of the chaperone function of $\alpha$-crystallin, suggesting that the two compounds are small chaperone inhibitors (Fig. 6). They showed better potency than the lead compound copalic acid in down-regulating AR and inhibiting cancer cell growth.

In summary, we lead optimized copalic acid in order to develop more potent AR down-regulating agents in prostate cancer cells. It has been well documented that AR still plays a critical role in prostate cancer even after the patients developed resistance to androgen receptor blocking agents. ${ }^{14}$ Down-regulating AR has been proposed as a new strategy for the endocrine therapy resistant prostate cancer treatment. ${ }^{8}$ Using small chaperone inhibitor to target AR has showed promising results in the clinical trial. However, 


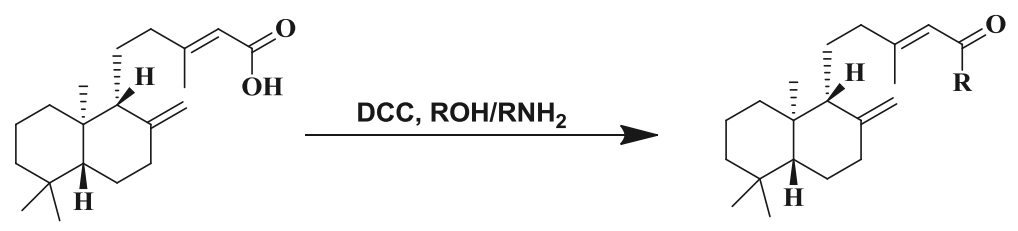<smiles>C/C=C1/CC[C@@H]2[C@H](CCCC2(C)C)[C@H]1CCC/C(C)=C\C(=O)Nc1ccc(Cl)cc1</smiles>

1<smiles>C=C1CC[C@@H]2[C@@H]3C/C(=C\C(=O)Nc4ccc(C)cc4)CC[C@@H]1[C@H]3CCCC2(C)C</smiles>

5<smiles>C=C1CC[C@@H]2[C@@H](CCCC2(C)C)[C@H]1CCC1=C/C(=C\C(=O)OC)C2C[C@H]12</smiles><smiles></smiles>

13

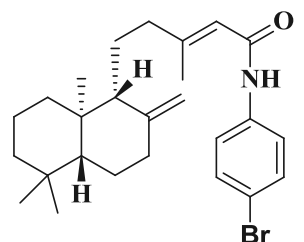

2

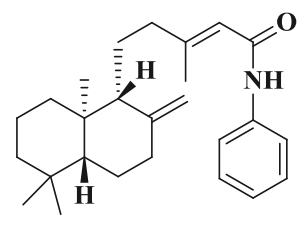

6<smiles>C=C1/C=C(/C=C(/C)CCCCCCC)[C@H](C)[C@@H]2CCCC(C)(C)[C@@H]1CC2</smiles><smiles>CNC(=O)/C=C1/C=C2CC[C@H]3C(C)CCC[C@H]3[C@H]2CC1</smiles><smiles>C=C1C=C2[C@@H](CCCC2(C)C)[C@@H]2C/C(=C/C(=O)Nc3ccc(I)cc3)CC[C@@H]12</smiles>

3<smiles></smiles>

7

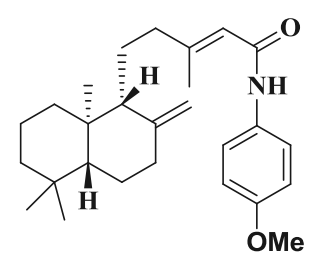

4

8<smiles>C=C1[C@H]2CC/C(=C/C(=O)NCc3ccccc3)CC[C@H]2[C@]2(C)CCCC(C)(C)C(=C)CC[C@@H]12</smiles>

11

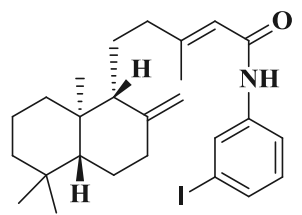

14

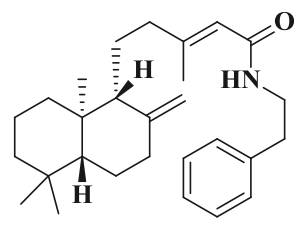

12

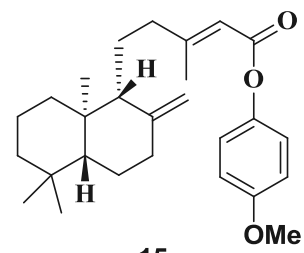

15

Fig. 3. Synthesis of the copalic acid analogs.

B-actin $-\infty$

B

Comp 4

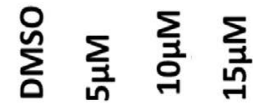

AR

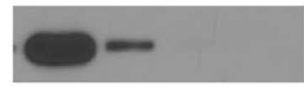

$\beta$-actin

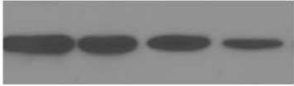

C

Comp 7

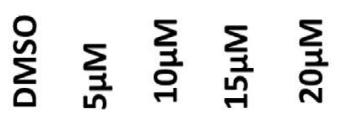

AR

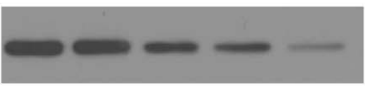

$\beta$-actin

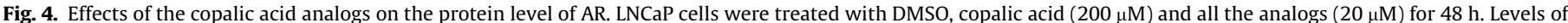

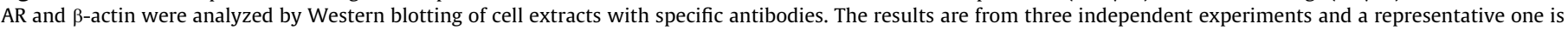
presented. (A) the screening of all the analogs; (B) dose dependent activity of compound 4; (C) dose dependent activity of compound 7 


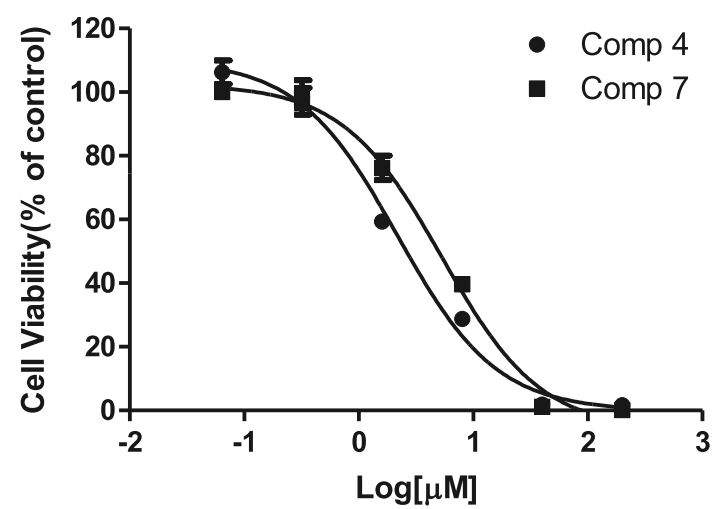

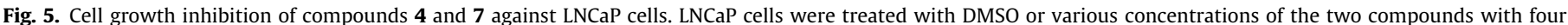
replications for $72 \mathrm{~h}$, and cell viability was determined with MTT assay.

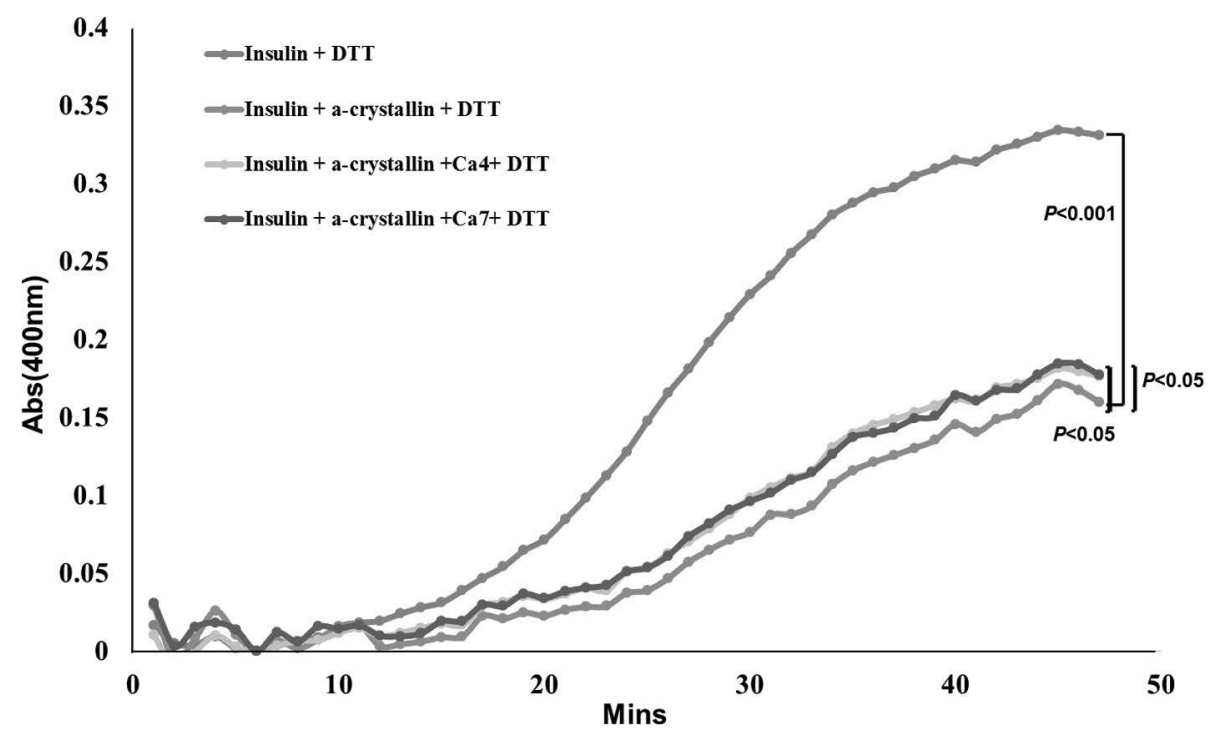

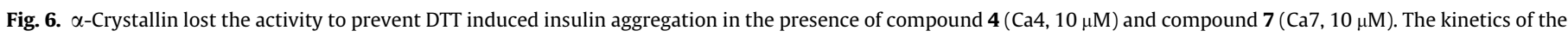

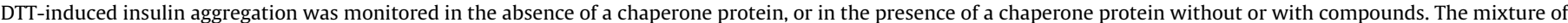

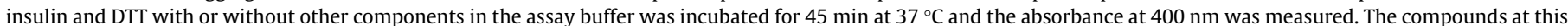

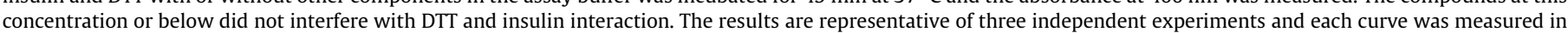

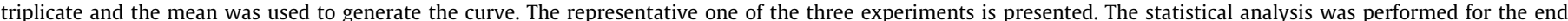
reading of the curve with unpaired $t$ test, the $p$ values are listed in the graph.

these strategies rely on ASO or siRNA to knockdown the small chaperone protein, and then decrease AR level. Our findings indicate that small molecule inhibitors have the capability to decrease AR level just like ASO or siRNA. We identified two small chaperone inhibitors that showed promising activity to down-regulate AR and inhibit prostate cancer cell growth, which supports our hypothesis that targeting AR with small molecule chaperone inhibitor is an effective approach for prostate cancer treatment or prevention.

\section{Acknowledgements}

This work was supported by Center for Gene Regulation in Health and Disease (GRHD) and summer undergraduate research program of Cleveland State University. Aicha Quamine was supported by McNair scholarship.

\section{References}

1. Leandro LM, Vargas Fde S, Barbosa PC, Neves JK, da Silva JA, da Veiga-Junior V. Molecules. 2012;17:3866.

2. Estevao LR, Medeiros JP, Baratella-Evencio L, Simoes RS, Mendonca Fde S, Evencio-Neto J. Acta Cir Bras. 2013;28:863.
3. Pieri FA, Mussi MC, Fiorini JE, Moreira MA, Schneedorf JM. Braz Dent J. $2012 ; 23: 36$.

4. Santos AO, Izumi E, Ueda-Nakamura T, Dias-Filho BP, Veiga-Junior VF, Nakamura CV. Mem Inst Oswaldo Cruz. 2013;108:59.

5. Lima SR, Junior VF, Christo HB, Pinto AC, Fernandes PD. Phytother Res. 2003; $17: 1048$

6. Faiella L, Piaz FD, Bisio A, Tosco A, De Tommasi N. Mol Biosyst. 2012;8:2637.

7. Lama R, Zhong B, Kulman D, Su B. Phytochem Lett. 2014;10:65.

8. Andrieu C, Taieb D, Baylot V, et al. Oncogene. 2010;29:1883.

9. Arts HJ, Hollema H, Lemstra W, et al. Int J Cancer. 1999;84:234

10. Concannon CG, Gorman AM, Samali A. Apoptosis. 2003;8:61.

11. Garrido C, Brunet M, Didelot C, Zermati Y, Schmitt E, Kroemer G. Cell Cycle. 2006;5:2592.

12. Garrido C, Bruey JM, Fromentin A, Hammann A, Arrigo AP, Solary E. FASEB J. 1999;13:2061.

13. Bruey JM, Ducasse C, Bonniaud P, et al. Nat Cell Biol. 2000;2:645.

14. Zoubeidi A, Zardan A, Beraldi E, et al. Cancer Res. 2007;67:10455.

15. Chi KN, Yu EY, Jacobs C, et al. Ann Oncol. 2016;27:1116.

16. Alpha-crystallin chaperone activity assay: $24 \mu \mathrm{l} 1 \mathrm{mg} / \mathrm{ml}$ insulin stock solution was added to the single well of 384 well plate, $3 \mu \mathrm{l} 5 \mathrm{mg} / \mathrm{ml}$ alpha-crystallin, $71 \mu \mathrm{l}$ PBS buffer with appropriate concentration of compound dissolved inside were added as well. The mixture was thoroughly mixed and incubated at $37^{\circ} \mathrm{C}$ for $5 \mathrm{~min}$, whereupon $2 \mu \mathrm{l}$ of $1 \mathrm{M}$ DTT in water was added to initiate the insulin aggregation. The absorbance (A) at $400 \mathrm{~nm}$ was monitored over $45 \mathrm{~min}$ using a plate reader. A mixture of insulin in the absence or presence of alphacrystalline with $0.1 \%$ DMSO was used as control.

Post-print standardized by MSL Academic Endeavors, the imprint of the Michael Schwartz 